\title{
Fecundity and Gonadal Maturity of Gongota Loach Somileptes Gongota (Hamilton) (Cobitidae) in the Habitat of the Someswari River
}

\author{
B. K. Saha and A. Saha \\ Fisheries Laboratory, Department of Zoology, Netrakona Govt. College, Netrakona, Bangladesh
}

\begin{abstract}
Fecundity and gonadal maturity of gongota loach, Somileptes gongota (=Cobitis gongota) (Ham.) were studied from October 2005 to September 2006. The fecundity of S. gongota varied from 1540 to 91500 . The average fecundity was calculated as $34916.85 \pm 25967.51$. The maximum and minimum fecundities were determined as $72520 \pm 13423.59$ and $2891.44 \pm 1084.19$ in June and March, respectively. The relationships between fecundity and other variables were calculated and found to be straight, linear and positively significant. The gonadal maturity of S.gongota was determined by using five methods viz. Percentage of gravid females against time, Gonado- Somatic Index (GSI), Gonadal-length Index (GLI), Ova Diameter (OD) and Colour of Ovary (CO). The highest percentages of gravid females were recorded as 100 in June and July. The overall percentage of gravid females was determined as $58.15 \pm 30.11$. The Gonado-Somatic Index level was recorded as 7.768 .66 with maximum $(26.17 \pm 3.13)$ in May. The Gonadal-Length Index level was determined as $35.34 \pm 10.40$ having the highest (50.31 \pm 3.04$)$ in May. The Ova Diameter ranged from 0.1-1.5 mm with a mean value of $0.53 \pm 0.3 \mathrm{~mm}$. The highest ova diameter was found to be $1.40 \pm 0.23 \mathrm{~mm}$ in June. The colour of ovary was recorded as reddish orange and orange in the months of May to June and July, respectively.
\end{abstract}

Key words: Fecundity, Gonadal maturity Ova diameter

\section{Introduction}

An important member in the freshwater fish fauna is the loaches (Family Cobitidae) and they are poorly explored in Bangladesh. Loaches in Bangladesh are represented by 6 genera (Rahman 1989). Most of them are of small size inhabiting the hillstreams, a few are also found in the rivers and swamps. The loaches being small in size do not form an important fishery anywhere in Bangladesh. Of these, Somileptes gongota (Hamilton), locally known as Pahari gutum, is distributed in the streams and rivers of Mymensingh, Sylhet Division and Rangpur district (Rahman 1989) has failed to draw the attention of the fishery biologists and only brief aspects of its biology are available (Shafi and Quddus 2004, Rahman 1989). The Dahaki river and the Rangapani canal near Jaintiapur in Sylhet, the Someswari river near Shusang Durgapur in Netrakona and the Mahananda river near Tetulia in Panchagarh are largely inhabited by the loaches. Besides Bangladesh, this species is also distributed all over India (Srivastava 1968, and Talwar and Jhingran 1991).

An understanding of the reproductive biology of fish is the basic requirements for the successful management and exploitation of fisheries resources (Lagler et al. 1962). The determination of breeding season is an essential part of biological investigations of fishes (Reddy 1979), which is done through the observation of gonadal maturity. No work has been done on the biology of this rare species, S. gongota from Bangladesh water bodies.

The present investigation has been carried out to determine fecundity and gonadal maturity of $S$. gongota inhabiting the Someswari river of Netrakona district. It may help to induce artificial breeding, culture practices and fishing of $S$. gongota.

\section{Materials and Methods}

The present study describes the data on fecundity, total length, standard length, total weight, gonadal length, gonadal weight, ova diameter and gonadal colour of the cobitid fish of Bangladesh. The fish samples were collected once a month during October 2005 to September 2006 at Shusang Durgapur of the Someswari river of Netrakona. A total number of 220 samples were collected by cast nets and drag nets, and only mature female fishes were selected for the study of gonadal maturity along with measurements of

\footnotetext{
*Corresponding author. E-mail: subrata_singha@ymail.com
} 
total length, total weight, gonadal length and gonadal weight, and estimation of fecundity. After collection, the fishes were preserved in $10 \%$ formalin. Measurements of fishes were taken by means of a measuring board fitted with a centimeter scale and their weights were also recorded by means of a sensitive Pan Balance. The fishes were sexed after dissecting out the gonads. After dissecting out the ovaries, the same procedure was applied for length and weight measurements after dehydration with blotting paper. Fifteen to twenty ova were collected at random sampling from anterior, central and posterior parts of each ovary of each fish. Diameters of the collected ova was measured with the help of ocular and stage micrometers and calculated by calibration (Each micrometer division having equivalent to $0.01 \mathrm{~mm}$ ). Colour of the ovaries was observed throughout the year. Gravimetric method (Lagler 1956) was used to determine fecundity. The values of the regression (b) and correlation (r) coefficients, 95\% confidence limits of the regression coefficient, the intercept and the standard deviation were calculated using statistical formulae according to Snedecor (1956) and Simpson et al. (1960) to establish mathematical relationship between fecundity and other variables.

Gonadal maturation of $S$. gongota was determined by using the following five methods: Percentage of gravid females against time, Gonado - somatic index (GSl), Gonadal length index (GLI), Ova diameter (OD) and Colour of ovary (CO). Gonado-somatic and Gonadal-length indices were calculated after Jhingran (1961) and Kader et al. (1988).

\section{Results and Discussion}

\section{Fecundity}

\section{Estimation of fecundity}

S. gongota is highly fertile and the number of eggs varied from 1540 (for a female of total length of $113 \mathrm{~mm}$ and total weight of $10.07 \mathrm{~g}$ ) to 91500 (for a female of total length of $122 \mathrm{~mm}$ and total weight of $15.85 \mathrm{~g}$ ). The average fecundity was calculated as $34916.85 \pm 25967.51$. (for the females of average total length of $115.74 \mathrm{~mm}$ and average total weight of $11.63 \pm 3.198 \mathrm{~g}$ ). The highest fecundity was $72520 \pm$ 13423.59 in June while the lowest fecundity was recorded as $2891.44 \pm 1084.19$ in March. The gonadal weight ranged from 0.11-4.40g showing the fecundity range of 1540-61600 eggs having total length and total weight from 9.8-11.8 mm and 3.57-14.20g, respectively. The gonadal length was found to be varied from 2.6 to $6.6 \mathrm{~mm}$ showing the fecundity range of 1625-66220 eggs in a total length and total weight of 10.6$12.4 \mathrm{~mm}$ and 6.0-15.95 g, respectively. Usually bigger fishes exhibited higher fecundity. The same sized fishes had different number of eggs in their ovaries. For example, 2 females of total length of $119.0 \mathrm{~mm}$ contained 3014 and 4788 eggs each inside their ovaries. Another 2 females of total length of $124.0 \mathrm{~mm}$ contained 4494 and 66220 eggs each. This type of variation is also common in other fishes (Islam and Hossain 1984, Saha et al. (2006) and Saha et al. 2007). According to Rahman (1990), the number of eggs of L. guntea varied from 4020 (total length of $62 \mathrm{~mm}$ and body weight of $2.2 \mathrm{~g}$ ) to 15250 (total length of $96 \mathrm{~mm}$ and body weight of $8.0 \mathrm{~g}$ ) with a mean value of $9664.92 \pm 13833.07$ eggs (mean total length of $80.01 \pm 11.86 \mathrm{~mm}$ and mean body weight of $4.57 \pm 2.02 \mathrm{~g}$ ) from Rajshahi.

The same weighed female fishes were found to have different fecundities, e.g., 2 females of total weight of $11.53 \mathrm{~g}$ contained 3014 and 4494 eggs. The females having same weighed ovaries were recorded to bear different fecundities, e.g., 2 females of ovary weight of $2.20 \mathrm{~g}$ contained 31460 and 36300 eggs.

\section{Fecundity and total length}

The variations in the fecundity have been shown in scattered diagram (Fig.1) of fecundity and total length expressing a

Table I: Regression coefficients with $\mathbf{9 5 \%}$ confidence limits, intercepts, standard deviation and correlation coefficients in the fecundity related different parameters of S.gongota

\begin{tabular}{l|c|c|c|c|c}
\hline Relationship & $\begin{array}{c}\text { Values of regression } \\
\text { coefficients (b) with } \\
95 \% \text { confidence limits }\end{array}$ & $\begin{array}{c}\text { Values of } \\
\text { intercepts } \\
\left(\mathrm{a}_{\mathrm{y}}\right)\end{array}$ & $\begin{array}{c}\text { Values of } \\
\text { standard } \\
\text { deviation of }\left(\mathrm{S}_{\mathrm{x}}\right)\end{array}$ & $\begin{array}{c}\text { Values of } \\
\text { correlation } \\
\text { coefficients }(\mathrm{r})\end{array}$ & $\begin{array}{c}\text { Significance of } \\
\text { r value at } \\
5 \% \text { level }\end{array}$ \\
\hline Fecundity-Total length & $11099.85 \pm 12239.97$ & -99555.87 & 0.8342 & 0.3498 & $\begin{array}{c}\text { Significant } \\
\text { Fecundity-Total weight }\end{array}$ \\
$5859.84 \pm 2372.696$ & -42346.26 & 3.2243 & 0.7131 & Highly Significant \\
Fecundity-Ovary length & $20814.86 \pm 6880.48$ & -75787.35 & 0.9915 & 0.7799 & Highly Significant \\
Fecundity-Ovary weight & $16960.07 \pm 2629.09$ & -71.15 & 1.4602 & 0.9358 & Most highly Significant \\
\hline
\end{tabular}


linear, positive and significant relationship between them. The results have been presented in Table. I.

The regression analysis of fecundity $(\mathrm{Y})$ on total length $(\mathrm{X})$ was evaluated as follows:

$$
\mathrm{Y}=-99556+11100 \mathrm{x}
$$

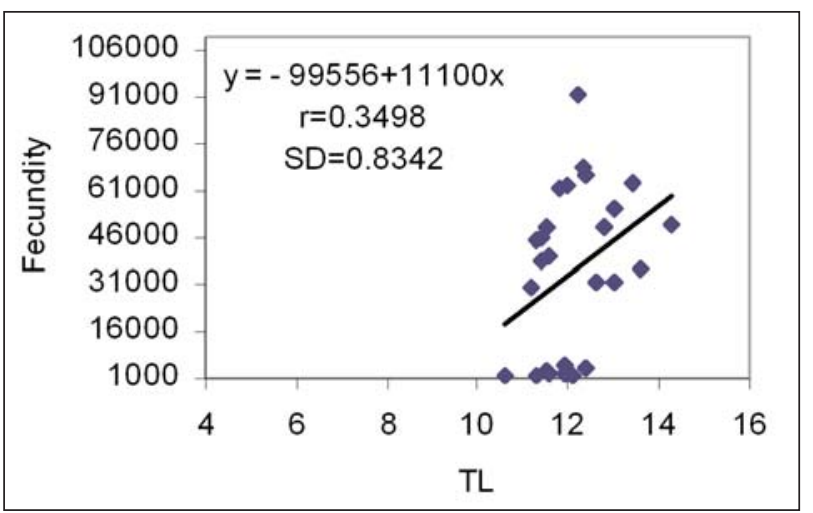

Fig. 1: Relationship between Fecundity (F) and Total Length (TL) of $S$. gongota

\section{Fecundity and total weight}

Scattered diagram of fecundity and total weight depicts a linear, positive and significant relationship between them. The values of the regression (b) and correlation (r) coefficients, $95 \%$ confidence limits of ' $b$ ', the intercept and the standard deviation have been shown in Table I.

The following equation was used to calculate regression values:

$$
Y=-42346+5859.8 X
$$

Shafi and Quddus (1974) obtained the similar result working on Puntius stigma from the Buriganga river of Dhaka.

\section{Fecundity and ovary length}

Scattered diagram (Fig. 2) of fecundity and ovary length clearly shows a linear relationship between them. Regression analysis of logarithm having fecundity (Y) on the logarithm of ovary length $(\mathrm{X})$ shows that their relationship is exactly linear, positive and highly significant. The values of the regression and correlation coefficients, the intercept and standard deviation have been shown in Table I. The equation used for determining the regression analysis was as follows:

$$
Y=-75787+20815 X
$$

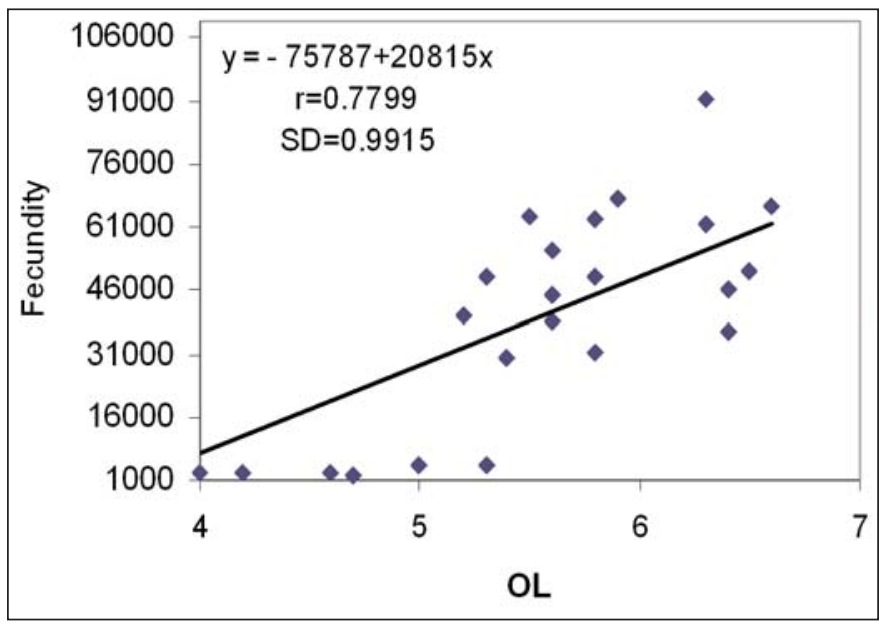

Fig. 2: Relationship between Fecundity (F) and ovary Length (OL) of $S$. gongota

The present finding is in conformity with the view of Shafi and Quddus (1974) who worked on Puntius stigma from the Buriganga river of Dhaka.

\section{Fecundity and ovary weight}

Scattered diagram (Fig. 3) of fecundity and ovary weight clearly shows a linear positive and highly significant relationship between them. The values of the regression and correlation coefficients, the intercept and standard deviation have been given in Table I.

The equation derived from the regression analysis was as follows :

$$
Y=-71.152+16960 X
$$

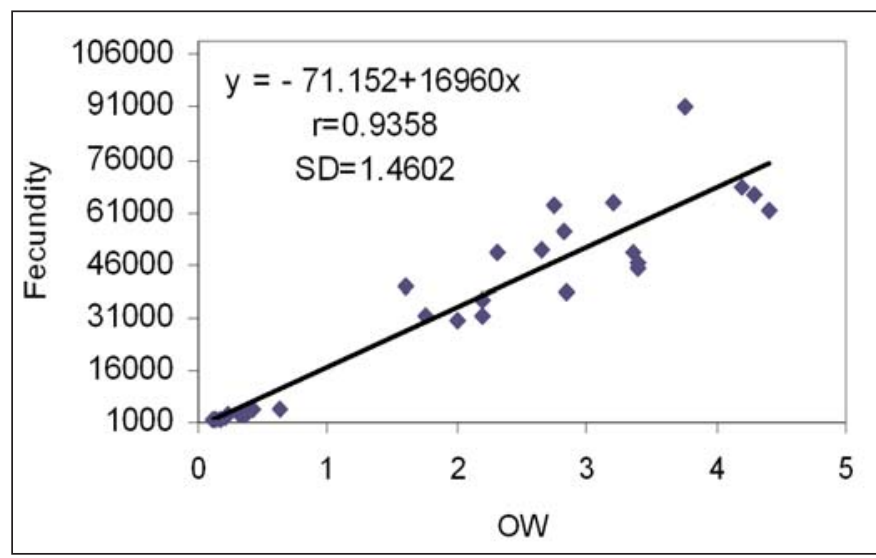

Fig. 3: Relationship between Fecundity (F) and ovary Weight $(\mathrm{OW})$ of $S$. gongota 
This finding is similar as reported by Shafi and Quddus (1974) in Puntius stigma from the Buriganga river of Dhaka.

\section{Monthwise fecundity}

The maximum and minimum fecundities of pahari gutum were recorded as $72520 \pm 13423.59$ in June and $2891.44 \pm$ 1084.19 in March, respectively. Fecundity of this species was not recorded in January, February, August, October, November and December, during the study period.

\section{Gonadal Maturity}

\section{Percentage of gravid females against time}

The overall percentage of gravid females was $58.15 \pm 30.10$ (Table II) Out of 140 females, 52 were gravid ones occurring in the months of March to July and September while no such fish was caught during the months of January, February, August and October-December. The maximum gravid females were found to occur in June (100\%) and July $(100 \%)$ and minimum in March (7.6\%) (Table II). From the observation of Rahman (1990), the percentage of gravid females of $L$. guntea is higher in the months of April to July with a peak in June.

\section{GSI level}

The weight of the ovaries increased gradually during the months of April to July attaining a peak in the month of May. The highest GSI level $(26.16 \pm 3.13)$ was recorded in the month of May. The overall GSI level was calculated as 7.76 \pm 8.66 (Fig. 4). The mean GSI level of L. guntea ranged from 2.27 in February to 24.13 in July (Rahman 1990).

\section{GLI level}

The length of the ovaries increased gradually from April to July showing a peak in May. The highest GLI level (50.31 \pm 3.03 ) was recorded in the month of May (Fig. 5). The overall GLI level was calculated as $35.34 \pm 10.40$. Rahman (1990) calculated the GLI level of L. guntea ranging from 18.98 in March to 44.94 in July from Rajshahi.

\section{Ova diameter (OD)}

The overall ova diameter was calculated as $0.53 \pm 0.30 \mathrm{~mm}$ (Table II). The minimum and maximum ova diameter were recorded as $0.1 \mathrm{~mm}$ in November and $1.5 \mathrm{~mm}$ in June respectively. The range of ova diameter of $L$. guntea was $0.20 \mathrm{~mm}$ in February to $0.47 \mathrm{~mm}$ in May according to the record of Rahman (1990). Shafi and Quddus (1974) observed the mean diameter of the eggs of Puntius stigma as $0.545 \mathrm{~mm}$ which is similar to this finding.

\section{Colour of ovary (CO)}

The colour of ovaries differed greatly in different months during the study period. Orange colour of ovaries was observed in the months of May - July while cream colour was in January, February, November and December, (Table II.

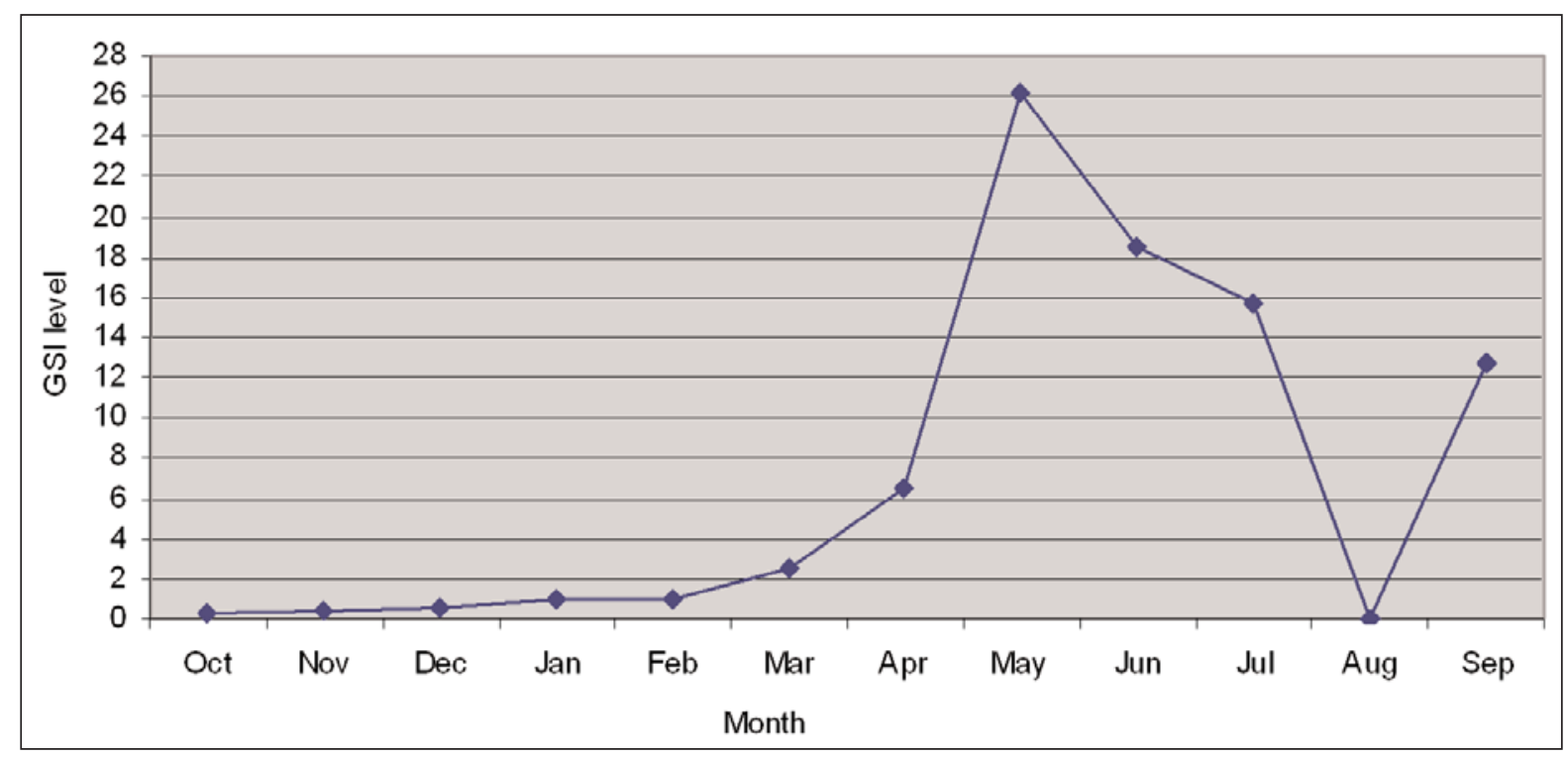

Fig. 4: Gonado-somatic index (GSI) level of different months of Pahari gutum (Somileptes gongota) 


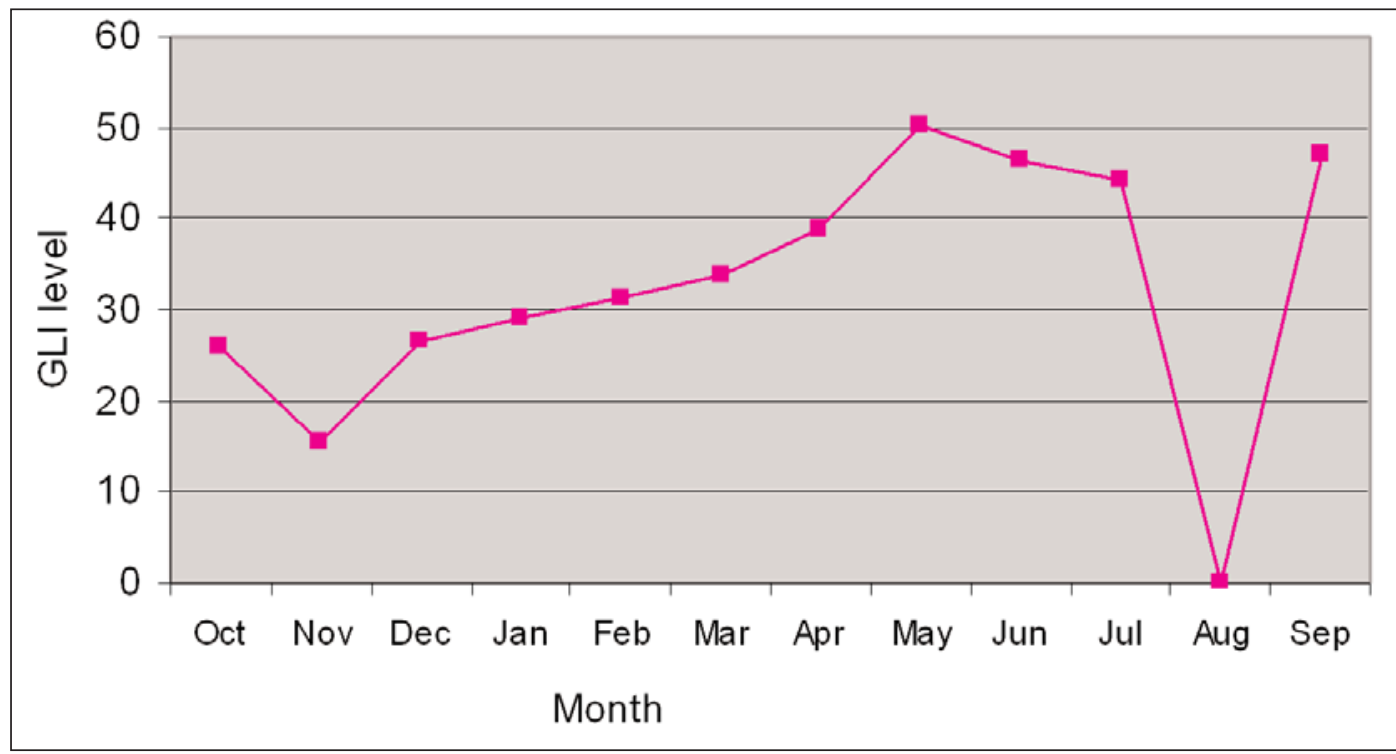

Fig. 5: Gonadal-length index (GLI) level of different months of Pahari gutum (Somileptes gongota)

Table II: Occurrence of gravid females, OD and colour of ovary of Pahari gutum (Somileptes gongota) caught from the Someswari river of Netrakona

\begin{tabular}{l|c|c|c}
\hline Months and year & Percentage of gravid females & $\mathrm{OD}(\mathrm{mm})$ Mean $\pm \mathrm{SD}$ & Colour of ovary \\
\hline Oct 2005 & 0 & $0.226 \pm 0.064$ & Brown \\
Nov 2005 & 0 & $0.338 \pm 0.196$ & Cream \\
Dec 2005 & 0 & $0.392 \pm 0.174$ & Cream \\
Jan 2006 & 0 & $0.43 \pm 0.11$ & Cream \\
Feb 2006 & 0 & $0.495 \pm 0.164$ & Cream \\
Mar 2006 & 61.54 & $0.476 \pm 0.103$ & Pink \\
Apr 2006 & 71.43 & $0.487 \pm 0.105$ & Yellow \\
May 2006 & 83.33 & $1.40 \pm 0.229$ & Reddish orange \\
Jun 2006 & 100 & $0.403 \pm 0.066$ & Reddish orange \\
Jul 2006 & 100 & 0 & Orange \\
Aug 2006 & 0 & $0.422 \pm 0.071$ & 0 \\
Sep 2006 & 66.67 & $0.53 \pm 0.303$ & Brown \\
Overall & $58.154 \pm 30.107$ & \\
\hline
\end{tabular}

This finding resembles the record of Saha et al. (2006) from Netrakona.

\section{Acknowledgement}

The authors are grateful to Professor Md. Ruhul Amin, Principal, Netrakona Govt. College, Netrakona for his sincere co-operation for providing the necessary facilities during the course of research work.

\section{References}

Islam M. S. and Hossain M. A. (1984). On the fecundity of chela Oxygaster bacaila (Ham) (Cypriniformes: Cyprinidae) from the river Padma. Univ. J. Zool. Rajshahi Univ., 3: 45-48.

Jhingran A. G. (1961). Studies on the maturity and fecundity of the Gangetic anchovy, Setipinna phasa (Hamilton). Indian J.Fish. 8: 291-312. 
Kader M. A., Bhuian A. L. and Manzur-i-Khuda A. R. M. M. (1988). The reproductive biology of Gobioides rubicundus (Ham.Buch.) in the Karnafuli river estuary. Chittagong. Indian J.Fish., 35: 139-250.

Lagler K. F. (1956). Enumeration of fish eggs. In Freshwater fishery, 2nd edition. W.M. Brown Company Publishers, Dubuque, 106-116.

Lagler K. F., Bardach J. E. and Miller R. R. (1962). Ichthyology. John Wiley \& Sons. Inc. New York, London, Sydney, pp. 271-274.

Rahman A. K. A. (1989). Freshwater Fishes of Bangladesh. Published by Zoological Society of Bangladesh, 364 pp.

Rahman M. H. (1990). Studies on some aspects of biology of Lepidocephalus guntea (Hamilton) (Cypriniformes : Cobitidae). M.Sc. Thesis (unpublished), Rajshahi University, Rajshahi, 127 pp.

Reddy B. P. (1979). Maturity and spawning in the murrel, Channa punctatus (Bloch, 1973) (Pisces, Teleostei, Channidae) from Guntur, Andhra Pradesh. Proc. Indian Nan. Sci. Acad, B 45(6): 543-553.

Saha B. K., Islam, M. R., Saha A. and Hossain M. A. (2006). Fecundity and gonadal maturation of clinbing perch Anabas testudineus (Bloch) from Netrakona. The Journal of NOAMI, 23(1) : 31-38.
Saha B. K., Islam M. R. and Saha A. (2007). Some aspects of the reproductive biology of the catfish Heteropneustes fossilis (Bloch) (Siluriformes : Heteropneustidae). J. Asiat. Soc. Bangladesh Sci., 33(1): 51-56, June 2007.

Shafi M. and Quddus, M. M. A. (2004). Bangladesher Matsho Shampad. Kabir Publications, Dhaka, Bangladesh, 440pp.

Shafi M. and Quddus M. M. A. (1974). The fecundity of the common punti, Puntius stigma (Cuvier \& Valenciennes) (Cyprinidae : Cypriniformes). Bangladesh J. Zool., 2(2) : 133-145.

Srivastava G. J. (1968). Fishes of Eastern Uttar Pradesh. Vishwavidyalaya Prakashan, Varanasi, 163 pp.

Talwar P. K. and Jhingran A. G. (1991). Inland Fishes. Vol. 1. Ixford \& IBH Publishing Co., New Delhi, India.

Simpson G. G., Roe A. and Lewontin R. C. (1960). Quantitative Zoology. Harcourt Brace \& Co., New York, 440 pp.

Snedecor G. W. (1956). Statistical methods. Lowa State University Press, Amer. Lowa, 534 pp.

Received : February, 02, 2010;

Accepted: March 29, 2011 